\title{
CONSTITUTIONAL GROWTH THROUGH RECALL OF DECISIONS
}

\author{
By Donald R. Richberg,
}

Director, Legislative Reference Bureau, Progressive Party, New York City.

Seldom has a political theory received so little unprejudiced consideration as the "recall of decisions." Bench and bar and the lay public have confused the idea with the recall of judges; have repeated catch phrases, such as- "the appeal from the umpire to the bleachers;" and largely overlooked the substance of the proposalan improved method only, for the exercise of a fundamental power reserved to the people, to make, to amend, and to interpret their constitutions.

The lack of a clear understanding of the proposal, rather than any vicious intention to misrepresent, is responsible for many unfair arguments against it. Lawyers, who should be better informed, repeat the stale misstatements of their professional brethren; and laymen, who have acquired a wholesome distrust of the advice of the bar, may be thereby unduly prejudiced in favor of the proposition.

It is possible that a presentation of the idea in words of one syllable may serve a double purpose in helping to clarify the real issue both for members of the bar and for the interested public. In order to simplify the exposition so far as possible, the present consideration will deal only with the recall of a limited class of "police power" decisions.

\section{Why and When Necessary}

In a certain class of important cases there may be, under the constitution of every state in the Union, a conflict of authority between the legislature and the courts.

Under the constitution the legislature of a state claims the power to pass a certain law-a law not prohibited by any definite words in the constitution.

Under the constitution the supreme court of the state claims the power to declare that particular law void.

Who is to decide between these two claims of power? 
The court may decide the case before it, but the court cannot decide the conflict in opinion between itself and the legislature.

Controversy has arisen between two arms of government of equal authority. No one can be assured whether the will of the people has been thwarted or upheld. A prudent regard for maintaining respect for the law and retaining confidence in the institutions of government requires a final adjudication of the controversy, which shall assure the supremacy of the will of the majority, as speedily as is consistent with intelligent consideration.

Clearly the only power superior to both the courts and the legislature lies in the people who made the constitutions which give the two conflicting bodies their authority.

Clearly the people can only exercise their power directly through the ballot box.

The truth of these conclusions is not to be disputed by any student of constitutional law or political science.

Controversy arises only over the question: How shall the people exercise their power to determine what the law shall be, when their representatives in the legislature and on the bench disagree?

The established method has been by amendment of the constitution.

The proposal made by Theodore Roosevelt before the Ohio Constitutional Convention was that in a certain limited class of cases a better method would be the "recall of decisions." This he has more recently described as the "review by the people of judgemade laws."

Neither of these terms, each being a definition of procedure, quite describes the purpose of the popular vote, which is-the decision by the people of a controversy between their courts and their legislature.

The courts are the guardians of the people's fundamental law -the constitutions. The legislatures are the makers of the people's ever-changing law-the statutes. Both the preservation of the principles of the fundamental law and the right to develop those principles in the changing statutes are essential to our form of government. In harmony they express the will of democracy. In conflict the law of the land becomes confused and uncertain.

In order to measure fairly the value of the new method for popular decision of such conflicts, one must have in mind the merits and demerits of the old method which it is sought to improve. 


\section{Why Constitutional Amendment is Inadequate}

In the first place the point of the proposal can be kept most clearly in mind by considering only the application of the "recall of decisions" to cases where the extent of the police power is the decisive issue.

The Progressive national platform has limited this doctrine and expressed the party position in the following language:

That when an act, passed under the pulice power of the state, is held unconstitutional under the state constitution, by the courts, the people, after an ample interval for deliberation, shall have an opportunity to vote on the question whether they desire the act to become a law, notwithstanding such decision.

To understand the reason for this limitation one must know what the "police power" is-a subject quite vague in the minds of laymen and none too clearly understood by many lawyers.

\section{What the Police Power Is}

When a people write a constitution they create the machinery of government. They establish a legislature to make new laws and to change old laws, in order to express the developing ideals of business and social morality. They designate and provide for the election of executives to administer these laws. Lastly they establish courts to decide controversies over private rights and over the powers and duties of public officers. A constitution gives certain powers to public servants and prohibits certain other powers and therefore contains both grants of authority and limitations of authority.

When the supreme court of a state upholds or denies the power of the legislature under the state constitution to pass a law, the decision will fall into one of two classes. It will be based on either:

(1) Definite power granted or denied in specific words or

(2) Broad power granted or denied in genin the state constitution. eral terms 


\section{The Present Consideration of the Recall of Decisions Deals Only with the Second Class of Cases}

A few examples of the type of constitutional provisions involved in the first class may be taken from the Constitution of the United States:

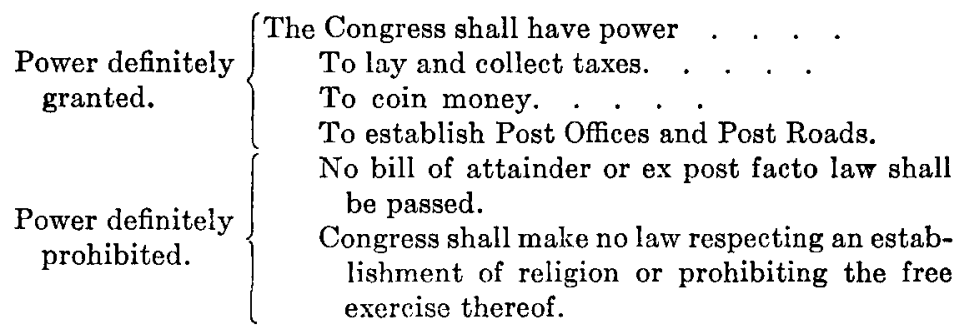

When a legislature exercises such a power definitely granted or prohibited and the supreme court interprets such definite language, there is no conflict of authority. If there is difference of opinion, even the legislators themselves will yield to the greater wisdom of the court in interpreting constitutional or statutory language. Nor would the average citizen care to act as a court of appeal.

In such a case the supreme court explains and enforces the constitution. If the language of the constitution no longer represents the will of the people the appropriate action to be taken by the people is to amend the constitution by altering its language.

But an entirely different situation is presented when constitutional questions arise in that twilight zone between broad powers granted and broad powers denied, in general language.

The most shadowy realm of all is between two provisions here quoted from the national Constitution but found in substance in practically all state constitutions:

\footnotetext{
Power broadly
granted. $\quad \begin{gathered}\text { The Congress shall have power } \\ \text { To provide for the common defense and general } \\ \text { welfare. } \\ \text { Power broadly } \\ \text { prohibited } \\ \text { proper for carrying into execution the foregoing } \\ \text { powers. }\end{gathered}$
} 
Between the above quoted granted power and prohibited power lies the great twilight zone of the "police power"-the power of the state to pass and enforce laws which are neither specifically authorized nor prohibited in the state constitution, but which are in aid of the general welfare.

If, for example, the state supreme court believes that a ten-hour law for women is necessary for the general welfare that law will be upheld as a proper exercise of the "police power."

If, however the state supreme court does not believe that such a law is necessary for the general welfare, the law will be held unconstitutional-as depriving women of "liberty" (the right to sell their labor for more than ten hours) without "due process of law."

The difference therefore between laws which are constitutional and unconstitutional, between what is "due process of law" and what is not, in such cases involving the "police power" does not depend upon any language in the constitution. These cases are decided solely upon the opinion of the court as to whether the law is necessary for the general welfare and hence authorized by the "police power."

As Mr. Justice Holmes of the United States supreme court has written, the extent of the "police power" depends upon "the prevailing morality or strong and preponderant opinion" of the time. ${ }^{1}$ Therefore a conscientious court will endeavor to express the will of the majority in its opinion. An obstinate, narrow-minded court will deceive itself as to what the "prevailing morality" demands. But in either case the decision will be based upon the opinion of the court concerning what laws are required in aid of the general welfare. If the court holds the law "unconstitutional," there are two conflicting authorities-the legislature and the court-one holding the law necessary to the general welfare, and the other holding the law not necessary to the general welfare. And there will be not one word in the constitution requiring either body to make or to annul the law.

Under those conditions it is simply pettifogging to say that "the judges are forced to their decision by their oaths to support the constitution." The legislators who passed the law took the same oath. Neither the legislators nor the judges would violate their oaths by reversing their action.

1 Noble State Bank vs. Haskell, 219 U. S. 104, 111. 
When, however, the "conscientious opinion" of a court voices the individual conscience of the judge in opposition to the expressed conscience of the people the fulfillment of the oath to preserve the constitution may be seriously questioned.

As stated in the beginning, there is in these "police power" cases a conflict between two arms of government and only the people who made both can decide which is right. Furthermore-since the whole question at issue is: What is demanded by the prevailing morality?-how could the correct answer be more surely ascertained than by taking a well-considered vote on the question?

The established method since this republic was formed for obtaining this vote has been to submit an amendment to the constitution covering the question at issue. There are two strong reasons why this method is inadequate and unsatisfactory in dealing with "police power" cases.

1. Amendment of the constitution is a slow, cumbersome process; not adapted to the need for settlement of a conflict between authorities over what is "constitutional."

2. There is nothing in the constitution to be amended.

Taking these points up in order:

\section{Amendment is a Cumbersome Process}

Careful deliberation in amending the grant of a power or the prohibition of a power is the part of wisdom. The fundamental law should be as solid as the foundations of a building - only to be rebuilt with great labor and caution. But in disputes between the courts and the legislature over the police power there is no fundamental question involved. The "police power" builds in the superstructure of government. The foundations remain unchanged, regardless of whether the court permits the legislative masons to put on another story or to remodel the interior.

Excessive deliberation is exasperating to a people determined to right industrial and social wrongs. If the court's opinion of the prevailing morality is correct, the sooner it is sustained the better. If the court's opinion is incorrect, the sooner it is reversed, the sooner will popular antagonism to the court subside-and respect for the law be restored. Of course a reasonable period of consideration is necessary in order that the popular verdict may express a conviction and not a transient emotion. 


\section{Amendment is an Inappropriate Process}

The strongest reason for a popular referendum on a "police power" decision is that there is nothing in the constitution to amend. There is no language to be altered, no new principle to be established. The legislature has the right to enact laws to promote the general welfare. The legislature has no right to take life, liberty or property without "due process of law." So it is and so it shall be. There is nothing for the people to amend in either the grant or the prohibition of power. It is also highly desirable that these two broad principles should not be qualified by a mass of formal exceptions.

The legislature and the courts have disagreed as to whether one particular law is necessary for the general welfare-is demanded by the "prevailing morality."

The people do not wish to change their constitution if they disagree with the supreme court. They simply wish to furnish conclusive evidence to the court of what the constitution as it is written authorizes, when interpreted in the light of the "strong and preponderant opinion" of the present generation.

Chief Justice Winslow of the supreme court of Wisconsin has written well and forcibly:

When an eighteenth century constitution forms the charter of liberty of a twentieth century government must its general provisions be construed and interpreted by an eighteenth century mind surrounded by eighteenth century conditions and ideals? Clearly not. This were to command the race to halt in its progress, to stretch the state upon a veritable bed of Procrustes.

Where there is no express command or prohibition, but general language and policy to be considered, the conditions prevailing at the time of its adoption must have their due weight, but the changed social, economic and governmental conditions and ideals of the time, as well as the problems which the changes have produced, must also logically enter into the consideration, and become influential factors in the settlement of problems of construction and interpretation.

A long list of decisions of state courts may be cited holding certain laws (largely "social and industrial justice" laws) unconstitutional as not "due process of law" and decisions by the United States supreme court holding similar laws constitutional as being "due process of law."'3

${ }^{2}$ Borgnis vs. Falk Company, 147 Wis. 327. 1911.

3Address on the "Recall of Decisions" by Albert M. Kales, before the Illinois Bar Association, April, 1912. 
Let us assume that the people would agree with the United States supreme court. Is it not a cumbersome, inept method for executing the popular will to require that in each of these cases an amendment to the constitution must be submitted to the people of the state and approved by popular vote and then that the legislature must reënact the same law previously passed? What is the logic of this long and laborious process? Why should a new clause be added to the constitution when no change in its language is necessary? Why should the complicated and expensive legislative machinery be again called upon to remake a law when the very vote of the people proves that the law was constitutionally enacted the first time?

The crux of the whole question is obtaining an expression, by popular vote, of "the prevailing morality or strong and preponderant opinion."

Why then submit the question as: "Shall the constitution be amended so as to empower the legislature to pass this law?"

The legislature has passed the law.

The supreme court has rendered an opinion that the law is not supported by the strong and preponderant opinion of the people.

The logical question to submit is:

"Did the legislature in passing this law represent the "prevailing morality or strong and preponderant opinion of the people?"

If the people answer "No," the opinion of the supreme court on this very question is sustained-because the court was right.

If the people answer "Yes," the opinion of the supreme court on this very question is overruled-because the court was-wrong.

In cases involving the "police power" of a state the review by the people of a decision would be logical procedure to attain a logical result. Amendment of the state constitution in such cases is an illogical means to an illogical end.

Compare the two in parallel columns:

In cases where a state supreme coult is of opinion that the "police power" of the state does not authorize the legislature to pass a certain law. Assume that the "strong and preponderant" opinion of the people favors the law. 


\section{Present Method by Amendment of Constitution}

Probable

Time

1 year

4-9 years

5-10 years

(1) Passed by legislature.

(2) Approved by governor.

(3) Held "unconstitutional" by atate supreme court.

(4) Constitutional amendment passed by legislature (once or twice) or initiated by the people.

(5) Constitutional amendment adopted by popular vote.

(6) The same act again passed by legislature.

(7) The same act again approved by governor.

(8) The same act held "constitutional" by state supreme court.

Finally becomes a law.

Proposed Method by Recall of DecisIons

AN ACT $\quad \begin{gathered}\text { Probable } \\ \text { Time }\end{gathered}$

(1) Passed by legislature.

(2) Approved by governor.

(3) Held "unconstitutional" by state supreme court.

(4) Petition for review of decision. Same purpose as constitutional amendment but more accurately expressed and more expeditious.

(5) Act approved and decision reversed by popular vote. Becomes a law.

(6) Unnecessary duplication.

(7) Unnecessary duplication.

(8) Only needed to correct errors in 6 and 7 which are omitted -hence useless.

$$
2 \text { years }
$$


Steps 6 and 7 are simply waste effort. The legislature and the governor have gone through the travail of creating a law-only to see it smothered by the court. Why create a similar law if the old one can be revived?

Step 8 gives the supreme court the ungracious task of reversing itself, with all the incentive naturally incident to that painful process to find technical flaws in the manner in which its opinion has been set aside.

When one contemplates the possible delay of ten years in correcting the mistake of the supreme court in interpreting the prevailing convictions of the time- one understands the reason for a deep resentment in the community against "judge-made law." A partly corrupt legislature is lashed by public opinion into passing a "general welfare" law over the protests of special interests. Then the supreme court, deaf to the prevalent voices of social reform, annuls the law. The whole bitter struggle must be fought over again: a constitutional amendment passed once or twice (many states require the passage twice), the law passed again, perhaps loaded with new "jokers" so that the court will again declare it void.

The struggle for social justice under such conditions is a disheartening battle against overwhelming odds.

To wait ten years for a law to fit the new needs of a rapidly changing civilization is often to make a farce of government. In ten years the automobile, once a rarity in the streets, dominates the traffic, wireless telegraphy remakes conditions of sea travel, the phonograph, the trolley car, the aeroplane, moving pictures, a score of new and important factors affect the daily life of the people. All industry undergoes like changes. New problems, responsibilities and community interests come upon us and must be reckoned with and the law must change to meet them.

The statement has been made that more fundamental changes in the industrial and social order occurred between A.D. 1800 and A.D. 1900 than in the thousand or even two thousand years preceding A.D. 1800. Have the constitutions changed to meet the new needs?

In The American Commonwealth, Mr. Bryce, commenting on the difficulty of amending the Constitution of the United States points out (p. 373) the results of a too rigid fundamental law in language which might well be applied to state constitutions which although more readily amended also require more frequent revision.

Since modification or developments are often needed and since they can rarely be made by amendment, some other way of making them must be found. 
The ingenuity of lawyers has discovered one method in interpretation, while the dexterity of politicians has invented a variety of devices whereby legislation may extend or usage may modify the express provisions of the apparently immovable and infexible instrument.

Amendment by construction, like executive non-enforcement of unpopular laws and indirect taxes, is a method of self-delusion which belongs to a passing school of politics. Fooling oneself is a rather stupid game and the American people show many signs of a presentday willingness to look facts in the face, to discuss the disagreeable truths of poverty and inefficiency as well as to orate about "prosperity" and the "land of the free and the home of the brave."

Our constitutions are human products with human imperfections and need constant improvement. Our judicial decisions, be they ever so honestly made, are the products of the education and environment of ordinary human beings-called judges. The ermine may require respect for the office but it does not guarantee the wisdom or social conscience of the wearer.

In the end faith in democracy requires a trust in the superiority of the ultimate judgment of the whole people over the immediate judgment of a few of the people. There is no reply to Lincoln's assertion that the people are the rightful masters of both their constitutions and their courts, except the denial of the capacity for self-government, which in itself is a repudiation of the constitutions and the courts of democracy.

Those who would enshrine the judiciary as "sacred" from the control of the people are not believers in democracy. And frank reactionaries freely state their conviction that the people must be "saved from themselves." By whom? Plainly, not by themselves.

There is in the end but one honest choice: either government is to be of the people, by the people and for the people, or of a few, by a few and for a few. History records no instance of permanent government of the few for the many. The benevolent rulers of one generation beget the hated tyrants of the next epoch. The "free and independent judiciary" enthroned above the will of "transient majorities" may all too easily become the reactionary, oppressive oligarchy that sets aside the legislative enactments of sovereign states, that coerces executives to refuse obedience to the expressed will of the people. 


\section{Summary}

Where the legislature and the courts disagree as to what the "prevailing morality" demands, the people alone can decide the controversy. In this way alone justice can be secured.

Amendment of constitutions is a cumbersome, inappropriate means for deciding conflicts between the legislature and the courts over the extent of the "police power."

The "recall of decisions" is a logical means since there is nothing in the constitution to amend, and the only question involved is: Did the court or the legislature correctly represent the "prevailing morality or strong and preponderant opinion" of the people?

The final issue between those intelligently favoring and opposing the "recall of decisions" is the world-old issue between democracy and oligarchy. Some believe in a divine favoritism in capacity for government. Others put their faith in the self-governing instinct of all mankind. To accept the sanctity of a judicial decision requires belief in the superhuman quality of the judge or in the inspired quality of his opinion. To accept the superiority of the crystallized opinion of all the people over the judgment of a few of the people requires faith in humanity itself.

There is the issue. The battle lines are drawn for the future, as in the past, between the conservative, fighting to retain the things that are, trusting to the wisdom of old counselors; and the progressive, pressing forward to what may be, with confidence in the greater wisdom of coming generations. 